\title{
REVIEWS
}

\section{Factors Influencing Immediate Maxillary Dental Implant Placement and Bone Resorption: A Review of the Literature and an Outlook on the Clinical Possibilities}

\section{Czynniki wpływające na natychmiastową implantację w szczęce i resorpcję kości - przegląd piśmiennictwa i opcji klinicznych}

Università degli Studi di Milano Bicocca, Italy

\begin{abstract}
The insertion of dental implants immediately after teeth extractions has become a routine clinical procedure in implant dentistry, despite difficulties derived from several factors influencing bone resorption. The aim of this study is to evaluate the survival rate of implant positioned immediately after tooth extraction in the upper maxilla and to analyze the surgical techniques and the parameters to minimize physiological bone resorption. An electronic search in MEDLINE (PubMed) and the Cochrane library was performed to analyze the factors that may influence physiological bone resorption during immediate implant placement: surgical technique, position of the implant and bone grafting. Immediate implant placement is a predictable technique with a high success rate. It does not prevent bone resorption subsequent to tooth extraction, but there are some parameters to take into account to minimize the bone resorption itself. Despite the high survival rate, more long-term studies are necessary to evaluate the success of implants placed immediately into fresh extraction sockets in the upper maxillary. Special attention has to be given to aesthetic outcomes (Dent. Med. Probl. 2016, 53, 3, 408-412).
\end{abstract}

Key words: dental implant, osteointegration, bone healing, alveolar bone loss, extraction sockets.

Słowa kluczowe: wszczep stomatologiczny, osteointegracja, gojenie się kości, zanik kości wyrostka, zębodół poekstrakcyjny.

The concept of osseointegration introduced by Branemark has literally revolutionized the standards of oral rehabilitation. Forty years ago the first implant was positioned to replace a missing tooth, an event that opened up new possibilities, both in terms of rehabilitation and aesthetics [1]. Originally, implantology aimed at stabilizing and ensuring the survival of the implant itself. But, over the years, as dental implant surgery has become a routine treatment, the aesthetic factor has become as important as the stability of the implant itself. Numerous studies have shown the high predictability of implant-supported rehabilitation and the high percentage of the long-term survival of intraosseous implants.

The 5-year survival rate is in fact about $95 \%$, and after 10 years it is about $89 \%$ [2]. In a litera- ture review, Gallucci et al. [3] reported that implants placed in the maxillary anterior aesthetic areas have a survival and success rate similar to that of other sectors. Henry et al. [4] found a success rate of $96 \%$ for implants placed to rehabilitate a single edentulous area in the anterior maxillary, a result comparable to the values of implant survival reported in literature, showing, however, a failure of the aesthetic result in $9 \%$ of cases. This underlines the importance of the aesthetic value as a key factor for the success of the implant and patient satisfaction.

As the years went by, the evolution of implant placement techniques brought to a reduction in the total time required for the treatment and, therefore, much attention has been focused on placement timing. A consensus report 
[5] has highlighted a number of advantages related to immediate implant placement in fresh extraction sockets, such as a reduction in the total time of treatment and a reduction in the number of surgical procedures. However, there are also some disadvantages, including the morphology of fresh extraction sockets and the inconsistency between the root anatomy and the shape of the dental implant, resulting in a discrepancy between the socket and the implant bed, which makes it more difficult to achieve primary implant stability. While in traditional implants the stability is provided by the contact of the implant with the newly formed bone in the socket, in immediate implant placement there is a bone defect, and stability can be obtained only by setting the implant in the apical part of the surgical site, in at least $4-5 \mathrm{~mm}$ of bone [5-7]. Moreover, we must also consider the residual bone defect between the implant and the walls of the socket and the processes of resorption and remodelling that occur after extraction [8].

It was thought that immediate implant placement could preserve the size of the bone, as well as reduce exposure time and the total time required for the treatment [8-12].

Although many authors have suggested that immediate implant placement in fresh extraction sockets can prevent physiological bone resorption following the extraction of a dental element, more recent studies have questioned this possibility [13-18].

\section{Material and Methods}

Through an analysis of the literature, we evaluated the immediate implant placement technique and the parameters that have to be taken into account in order to minimize the physiological process of bone resorption: extraction technique, position of the implant, grafting material, presence of endodontic-periodontal lesion.

An electronic search in MEDLINE (PubMed) and the Cochrane library was performed. Studies were selected due to their relevance to the topic. Moreover, manual searches of the bibliographies of all full text articles were also conducted.

\section{Results}

\section{Extraction Technique}

The surgical procedure of immediate implant placement includes the following steps: tooth ex- traction with or without access flap; implant site preparation and implant placement with possible regeneration; primary wound closure of the surgical site.

The extraction of the tooth must be the least traumatic possible. From an aesthetic point of view the most important thing to consider when rehabilitating the area with a dental implant is preserving the vestibular cortical bone structure and soft tissues. In immediate implant placement procedures, the elevation of a full thickness buccal flap should be avoided, since it compromises the bony blood supply.

The use of periotomes is recommended: this instrument should be placed using pressure in the apical direction to separate the most coronal part of the periodontal ligament from the cement of the tooth.

No pressure must be used in the buccal-palatal/lingual direction, as this may damage the vestibular cortical structure of the alveolar socket. However, rotational forces in the coronal and mesial-distal directions can be applied.

Sometimes the use of high-speed rotating tools may be required to perform a mesial or distal ostectomy and facilitate the extraction. To preserve the hard tissue as much as possible, the ostectomy should not be performed on the vestibular area.

After tooth extraction, the walls of the socket must be carefully examined to assess their integrity. The socket is carefully curetted and the entire area is thoroughly rinsed with a saline solution. There must be a bit of bleeding, so that a stable clot can be formed that will initiate the subsequent healing phases $[7,8,19]$.

\section{Diagnosis and Implant Placement}

The main factors to be analysed for immediate implant placement are the following:

- stability of the peri-implant soft tissue;

- vestibular bone thickness;

- any periapical infective processes;

- direction and depth of implant placement;

- peri-implant bone defect and possible GBR and ridge preservation.

The success of implant-prosthetic rehabilitations, from an aesthetic and functional point of view, depends on the three-dimensional position of the implant within the alveolar bone.

The implant must be considered as the apical extension of the prosthetic reconstruction, and it is the prosthetic reconstruction itself that must determine the site of implant placement $[20,21]$. This concept is known as prosthetically driven implant placement, which means that the implant must be 
placed where it can be properly prosthesized. This is in contrast with the previous concept of implant placement determined by bone anatomy.

The three-dimensional placement of the implant is extremely important. If the implant follows the vestibular direction, this will complicate its prosthetic rehabilitation and may also result in a dehiscence of the vestibular cortical bone and lead to a high risk of gingival resorption. The implant shoulder should be placed at least $2 \mathrm{~mm}$ palatally to the vestibular bone crest [22].

Implant placement into fresh extraction sockets fail, as previously said, to fully counteract the dimensional variation of the alveolar ridge due to bone resorption; however, the correct placement in the vestibular-palatal direction is extremely important to best preserve the vestibular cortical bone. A clinical study conducted by Evans and Chen [23] showed that implants whose shoulders were placed in the vestibular direction or coincided with a line passing through the cervical margin of the adjacent teeth led to a recession of the vestibular tissue three times higher than implants placed in the lingual direction (1.8 vs $0.6 \mathrm{~mm}$ ) [23, 24].

In relation to the proper buccolingual positioning of implants, Buser et al. [25] recommend to place the implant at a distance of $2 \mathrm{~mm}$ palatally to the vestibular bone crest, to ensure adequate maintenance of the thickness of the bone crest itself, which is proven to be a decisive factor for vestibular tissues maintenance.

The mesiodistal space available when placing individual implants should also be evaluated for good planning. An implant too close to the adjacent tooth can lead to a loss of the interproximal bone with a consequent collapse of the papilla $[26,27]$. Based on these considerations, it was determined that an implant should be placed at a minimum distance of $1.5-2 \mathrm{~mm}$ from the adjacent tooth, and, in the case of multiple implants, we must preserve a space of 3-4 $\mathrm{mm}$.

\section{Grafting}

The theory that suggests that immediate implant placement can prevent bone resorption following the extraction of a dental element has been questioned by many clinical studies. By placing the implants on fresh extraction sites, the authors found vertical resorptions of the buccal cortical plate corresponding to $2.6 \mathrm{~mm}, 2.5 \mathrm{~mm}$ and $2.8 \mathrm{~mm}$ [15-18].

Implementing bone grafts (heterologous or synthetic materials) into the socket after placing an implant can partially compensate for the dimensional resorption, which occurs after tooth extraction, and can also fill bone dehiscence and fenestrations. Bone substitutes maintain more stable volumes over time, as they show a slower resorption compared to autologous bone. This characteristic makes them more suitable for filling peri-implant spaces and for preserving horizontal bone volumes [28]. Iasella et al. [29] have compared the values obtained in patients whose cavity was filled with FDBA (freeze dried bone allograft) allogeneic material and covered with collagen membrane with those seen in patients in which the socket had been left to heal without any grafts. The results showed that the decrease in crestal bone thickness was, on average, $1.7 \mathrm{~mm}$; the sockets in which a bone substitute had been positioned showed, on the other hand, a decrease of only $1.2 \mathrm{~mm}$.

As for the vertical resorption, the variation in the height of the vestibular cortical bone was reduced from $1.3 \pm 2.0 \mathrm{~mm}$ in subjects who underwent bone grafting to $0.9 \pm 1.6$ in subjects who did not undergo the same procedure. As for resorption in the cortical palatal/lingual area, however, the authors found no statistically significant differences [22, 25, 29].

In some cases, moreover, as indicated by the values mentioned above, there has been a vertical increase in bone dimension, where a ridge preservation procedure was performed.

\section{Vertical and Horizontal Bone Resorption Following Immediate Implant Placement}

The thickness of the vestibular cortical bone and the gap between the implant and the vestibular cortical bone are extremely important in influencing the horizontal resorption of the alveolar ridge following tooth extraction [30]. A study by Huynh-Ba et al. [31] has shown that only a small portion of maxillary front teeth have a vestibular bone thickness greater than or equal to $2 \mathrm{~mm}$ (6.5\%). As many as $78 \%$ of dental elements have a vestibular bone thickness less than $1 \mathrm{~mm}$ and $46 \%$ even less than or equal to $0.5 \mathrm{~mm}$. Lindhe et al. [24] have shown that the average horizontal resorption of the alveolar ridge was equal to $1.2 \mathrm{~mm}$ in patients with a thin vestibular cortical bone $(<1 \mathrm{~mm})$ compared to a lower average resorption in patients with a thick cortical bone equal to $0.9 \mathrm{~mm}$. Similarly, the values of vertical resorption were measured: $-1.2 \mathrm{~mm}$ versus $-0.4 \mathrm{~mm}$ in patients with a cortical bone of $<1 \mathrm{~mm}$ and $>1 \mathrm{~mm}$, respectively. The studies show that a thin vestibular cortical bone can lead to a greater degree of resorption, both vertical and horizontal, of the bone crest [24].

Spray et al. [32], with a study conducted on the analysis of peri-implant bone values, mea- 
sured over 3,061 implants and have come to the same conclusion as well. With a vestibular cortical bone thickness greater than $1.8 \mathrm{~mm}$, there is a reduced buccal/palatal thickness, compared to other sites with a thinner cortical bone.

More recent nine-year follow-up studies show that bone grafting in the peri-implant defect performed simultaneously with immediate implant placement offers high aesthetic predictability, since in $95 \%$ of cases the vestibular cortical bone of fresh sockets remains preserved [33].

\section{Discussion}

This work has analysed the predictability, survival rate, surgical technique, treatment plan, advantages and disadvantages of immediate implant placement in the maxillary aesthetic area.

Although we cannot completely counteract bone resorption typically connected to a fresh extraction socket, the reduction of the total time of rehabilitation is the most apparent advantage of immediate implant placement compared to traditional techniques, which require a healing time of approximately 3-6 months. The aesthetic result and the survival rate are similar to those obtained in other areas of the oral cavity and with non-immediate implant placement.

The use of bone grafts to treat peri-implant defects is the gold standard to limit resorption, which is difficult to counteract and appears to be linked mainly to the anatomy of the alveolar ridges of single individuals. From a statistical point of view, it can be said that $1.8 \mathrm{~mm}$ is the critical thickness of the cortical bone, below which the operator should expect greater crestal bone resorption [32].

Immediate dental implant placement results in a reliable treatment outcome in terms of implant survival and minimal change of peri-implant soft and hard tissue dimensions, even though some other factors not included in the present work may affect the outcomes of procedures other than the timing of implant placement alone, such as the bone quality, the primary stability, the dimension of the edentulous area and the patient anamnesis.

The timing of implant restoration is one of the key points in immediate implant positioning, in view of the current trend towards decreasing the total treatment time, while maintaining clinical and aesthetic outcomes at the highest possible level. Achieving prompt aesthetic results with immediate provisionalization is one of the aims of implants placed immediately into fresh extraction sockets, with restorations that should be free of contact in centric occlusion and during excursive movements to limit implant micromovements. The clinician should consider the optimal strategy on a case-by-case basis. Concerning the aesthetic results, further studies are required, given the difficulty to give standardised assessments. This technique, anyway, shows high predictability and a high success rate.

\section{References}

[1] Brånemark P.I., Adell R., Breine U., Hansson B.O., Lindström J., Ohlsson A.: Intra-osseous anchorage of dental prostheses. I. Experimental studies. Scand. J. Plast. Recons. 1969, 3, 81-100.

[2] Lang N.P., Berglundh T., Heitz-Mayfield L.J., Pjetursson B.E., Salvi G.E., Sanz M.: Consensus statements and recommended clinical procedures regarding implant survival and complications. Int. J. Oral Max. Impl. 2004, 19, Suppl, 150-154.

[3] Gallucci G.O., Grütter L., Chuang S.K., Belser U.C.: Dimensional changes of peri-implant soft tissue over 2 years with single-implant crowns in the anterior maxilla. J. Clin. Periodontol. 2011, 38, 293-299.

[4] Henry P.J., Laney W.R., Jemt T., Harris D., Krogh P.H., Polizzi G., Zarb G.A., Herrmann I.: Osseointegrated implants for single-tooth replacement: a prospective 5-year multicenter study. Int. J. Oral Max. Impl. 1996, 11, 450-455.

[5] Hämmerle C.H., Chen S.T., Wilson T.G. JR.: Consensus statements and recommended clinical procedures regarding the placement of implants in extraction sockets. Int. J. Oral Max. Implants, 2004, 19, Suppl, $26-28$.

[6] LANG N.P., Lui P., LAU K.Y., Li K.Y., Wong M.C.M.: A systematic review on survival and success rates of implants placed immediately into fresh extraction sockets after at least 1 year. Clin. Oral Implants Res. 2012, 23, Suppl 5, 39-66.

[7] Rosenquist B., Grenthe B.: Immediate placement of implants into extraction sockets: Implant survival. Int. J. Oral Max. Impl. 1996, 11, 205-209.

[8] Lazzara R.J.: Immediate implant placement into extraction sites: Surgical and restorative advantages. Int. J. Periodont. Rest. 1989, 9, 332-343.

[9] Denissen H.W., Kalk W.: Preventive implantations. Int. Dent. J. 1991, 41, 17-24.

[10] Denissen H.W., Kalk W., Veldhuis H.A., van Waas M.A.: Anatomic consideration for preventive implantation. Int. J. Oral Max. Impl. 1993, 8, 191-196.

[11] Sclar A.G.: Preserving alveolar ridge anatomy following tooth removal in conjunction with immediate implant placement. The biocol technique. Atlas Oral Maxillofac. Surg. Clin. North Am. 1999, 7, 39-59.

[12] Covani U., Barone A., Cornelini R., Crespi R.: Soft tissue healing around implants placed immediately after tooth extraction without incision: A clinical report. Int. J. Oral Max. Impl. 2004, 19, 549-553. 
[13] Lindquist L.W., Rockler B., CARLSSON G.E.: Bone resorption around fixtures in edentulous patients treated with mandibular fixed tissue-integrated prostheses. J. Prosthet. Dent. 1988, 59, 59-63.

[14] Von Wowern N., Harder F., Hjørting-Hansen E., Gotfredsen K.: ITI implants with overdentures: A prevention of bone loss in edentulous mandibles? Int. J. Oral Max. Impl. 1990, 5, 135-139.

[15] Araujo M.G., Lindhe J.: Dimensional ridge alterations following tooth extraction. An experimental study in the dog. J. Clin. Periodontol. 2005, 32, 212-218.

[16] Araujo M.G., Sukekava F., Wennstrom J.L., Lindhe J.: Tissue modelling following implant placement in fresh extraction sockets. Clin. Oral Implant. Res. 2006, 17, 615-624.

[17] Araujo M.G., Wennstrom J.L., Lindhe J.: Modelling of the buccal and lingual bone walls of fresh extraction sites following implant installation. Clin. Oral Implants Res. 2006, 17, 606-614.

[18] Botticelli D., Persson L.G., Lindhe J., Berglundh T.: Bone tissue formation adjacent to implants placed in fresh extraction sockets. An experimental study in dogs. Clin. Oral Implants Res. 2006, 17, 351-358.

[19] Anson D.: Maxillary anterior esthetic extractions with delayed single-stage implant placement. Compend. Contin. Educ. Dent. 2002, 23, 829-380, 833-836.

[20] Garber D.A., Belser U.C.: Restoration-driven implant placement with restoration-generated site development. Compend. Contin. Educ. Dent. 1995, 16, 796, 798-802, 804.

[21] Garber D.A.: The esthetic dental implant: Letting restoration be the guide. J. Am. Dent. Assoc. 1995,126, $319-325$.

[22] Capelli M., Deflorian M.A., Scaini R., Galli F., Parenti A., Fumagalli L., Zuffetti F., Testori T.: Analisi critica dei fattori di rischio estetici in implantologia post-estrattiva. Implants, 2012, 1, 6-14 [in Italian].

[23] Evans C.D., Chen S.T.: Esthetic outcomes of immediate implant placements. Clin. Oral Implants Res. 2008, 19, 73-80.

[24] Tomasi C., Sanz M., Cecchinato D., Pjetursson B., Ferrus J., Lang N.P., Lindhe J.: Bone dimensional variations at implants placed in fresh extraction sockets: A multilevel multivariate analysis. Clin. Oral Implants Res. 2010, 21, 30-36.

[25] Buser D., Martin W., Belser U.C.: Optimizing esthetics for implant restorations in the anterior maxilla: Anatomical and surgical considerations. Int. J. Oral Max. Impl. 2004, 19, Suppl. 43-61.

[26] Tarnow D.P., Cho S.C., Wallace S.S.: The effect of inter-implant distance on the height of interimplant bone crest. J. Periodontol. 2000, 71, 546-549.

[27] Esposito M., Ekestubbe A., Grondahl K.: Radiological evaluation of marginal bone loss at tooth surfaces facing single Branemark implants. Clin. Oral Implants Res. 1993, 4, 151-157.

[28] Grunder U.: Stability of the mucosal topography around single-tooth implants and adjacent teeth: 1-year results. Int. J. Periodontics Restorative Dent. 2000, 20, 11-17.

[29] Iasella J.M., Greenwell H., Miller R.L., Hill M., Drisko C., Bohra A.A., Scheetz J.P.: Ridge preservation with freeze-dried bone allograft and a collagen membrane compared to extraction alone for implant site development: A clinical and histologic study in humans. J. Periodontol. 2003, 74, 990-999.

[30] Ferrus J., Cecchinato D., PJetursson B., Lang N., Sanz M., Lindhe J.: Factors influencing ridge alterations following implant placement in the fresh extraction socket. Clin. Oral Implants Res. 2010, 21, 22-29.

[31] Huynh-Ba G., Pjetursson B.E., Sanz M., Cecchinato D., Ferrus J., Lindhe J., Lang N.P.: Analysis of the socket bone wall dimensions in the upper maxilla in relation to immediate implant placement. Clin. Oral Implants Res. 2010, 21, 37-42.

[32] Spray J.R., Black C.G., Morris H.F.: The influence of bone thickness on facial marginal bone response: Stage 1 placement through stage 2 uncovering. Ann. Periodontol. 2000, 5, 119-128.

[33] Buser D., Chappuis V., Bornstein M.A., Wittneben J.G., Frei M., Belser U.C.: Long-term stability of contour augmentation with early implant placement following single tooth extraction in the esthetic zone: A prospective, cross-sectional study in 41 patients with a 5- to 9-year follow-up. J. Periodontol. 2013, 84, 1517-1527.

\section{Address for correspondence:}

Edoardo Bianco

Corso Cavour 11

28100 Novara

Italy

E-mail: edoardowhite@gmail.com

Conflict of Interest: None declared

Received: 19.04.2016

Revised: 8.05.2016

Accepted: 15.05.2016 